\title{
A Historical View on Health Care: A New View on Austerity?
}

\author{
Caitjan Gainty ${ }^{1}[$
}

Published online: 27 June 2019

(c) The Author(s) 2019

\begin{abstract}
It is an axiom of contemporary conversations about austerity and health care that the relationship between the two is essentially direct. Cutting funds damages health care systems and hurts the health of individuals who rely on them. Though this premise has provoked necessary discussion about global politics, the global economy and their impact on individual well-being, it is nonetheless intrinsically problematic. Assigning health and health care as objects of austerity not only obscures the complexity of health care systems and the opacity of health's definitional borders, but also misunderstands austerity, its manifestations and its significance. The ambition of this essay is to bring health care back into the debate, in order to establish the greater dynamism of the contemporary austerity and health care relationship. This historical reconstruction will challenge the significance of our current situating of austerity as health care's bogeyman, press for a reconsideration of our contemporary definitions of the key factors involved here (health, health care and austerity) and finally conclude with some thoughts on how we might more productively approach the problem of health now.
\end{abstract}

Keywords Austerity $\cdot$ History $\cdot$ Health care $\cdot$ Health

It is not especially controversial to suggest in a publication like this that austerity has been a failure [1, 2, 5, 22, 23, 28, 32, 34-37, 40, 43]. Many commentators have given evidence that belt-tightening measures imposed after the global financial crisis of 2008 have not righted the economic ship, and that a decade of cuts to welfare spending has had a grossly detrimental impact on health and wellbeing [1, 34, 36]. Defunding state services upon which health depends-including sanitation and infrastructural safety-did, does, and will likely always have a detrimental effect on the health of the public $[1,5,22,23,28,32,34,36,40,43]$.

There is no need to belabour these points. Instead, this article will examine a more ineffable, but no less important way in which austerity relates to health, namely as

Caitjan Gainty

caitjan.gainty@kcl.ac.uk

1 Department of History, King's College, London, UK 
a rhetorical smokescreen obscuring problems intrinsic to the health care system we have inherited. Rather than acknowledging that some of the problems highlighted in the name of austerity are historically specific responses to a longer story about the history of health and health care as these have developed over the last several centuries, we often treat health care as a morally benevolent system that, where it fails, fails as a result of external factors that act upon it. While it is in one sense no doubt true that, as one commentator articulated, ill health is the embodiment of austerity, in another sense, the more important point is that ill health is just as much, if not more so, the embodiment — the creation, in fact—of medicine itself [36].

This is the relationship that we will explore and flesh out a bit here, along two lines of enquiry. We will first trace the earlier history of modern medicine, examining the ways in which the system of medical care that we know today was built, and demonstrating how ill health as an object of health care was constructed over this period-not as a result of any kind of particular imperative on the part of medicine to care, but instead, as the locus in which newly defined categories of disease could be placed. This was a system that worked, in some senses, not in spite of, but because of its ability not to care about individuals in the particular [14]. This done, we will move forward to a later point in this history, observing the ways in which the expectations for health care shifted in the late 20th century, when our current mismatch, between the 'care' that we demand from medicine and its longer-standing epistemological imperative not to care in order to cure, came to be.

It is important to note at the outset that this article is not intended as a critique of the logic of past or current medical practice. Nor is it meant to reflect on the validity of the efforts of those within medical spheres to address the imbalances between expectations for health care and its systemic possibilities touched upon here. This work similarly does not take a stand about what medicine ought to look like or about whether the current focus on 'caring' is better than the focus that preceded it. Its aspirations are in fact much simpler, seeking only to situate these questions in a longer, contingent history of medicine in order to demonstrate the ways in which the rhetoric of austerity we deploy today often works against a more complex understanding of medicine and its epistemological underpinnings. If this story does have a moral, it is this: we can and should distinguish between the many forces, external and internal, that impact health care as we know it. Indeed, we must do this if we want to understand the roots of our dissatisfaction with health care and then map and create the reforms that we would like to see.

\section{Building Health Care}

It would be impossible to pinpoint a single point of origin for our current iterations of health and health care, though, for the sake of convention, historians have generally considered their emergence as a 19th century phenomenon. In the opening decades of the 1800s, long before the germ theory of disease had fully taken hold, a new form of medical thinking had already started to gain sway. It marked a pronounced shift in medicine, from an embrace of healing practices and treatments which had been aimed to address the specific circumstances of a patient-whether 
constitutional, environmental or circumstantial - and toward the establishment of disease as an abstracted, intellectual entity. It's hard to overemphasise how fundamental this shift in attention from the particular to the general, and from the individual to the disease, actually was. The eminent historian of medicine Charles Rosenberg has likened it in significance to the revolutions in thought led by Darwin, Newton and Freud, with one key difference: these thinkers and their work have been given place in history as heralds of a sea change, while medicine's transformation is still largely unrecognised [33].

As one might well imagine, in the midst of this slow re-orientation, many nineteenth century health practitioners were sceptical that this abstracted approach to health represented a legitimate therapeutic way forward. As the physician John Robertson wrote in 1827, "The degree to which diseases are modified by constitution, season, climate and an infinite variety of accidental circumstances renders at least doubtful the notion that formal categories of disease could be transformative for medicine" [33]. To others like him, this new idea was on its face nonsensical. How could an individual body, comprised of the unique tendencies that made it individual in the first place, be accounted for by a system that required, in order to work, the interchangeability of symptoms and disease presentations across whole populations? Disease categories might be useful, they opined, but likely only as part of a larger medical armamentarium.

Despite its detractors, however, this new methodology was moving ahead, buoyed by the larger movement toward statistical thinking more generally. As the statistician William Farr put it in 1842,

The advantages of a uniform statistical nomenclature, however imperfect, are so obvious, that it is surprising no attention has been paid to its enforcement... Each disease has, in many instances, been denoted by three or four terms, and each term has been applied to as many different diseases: vague, inconvenient names have been employed, or complications have been registered instead of primary diseases. The nomenclature is of as much importance in this department of inquiry as weights and measures in the physical sciences, and should be settled without delay [8].

This tendency toward standardisation and classification took even firmer root within the practice of medicine itself in the early twentieth century, when various entities within and outside medicine pushed for the standardisation of medical spaces, medical diagnosis and treatment, medical education and the establishment of a new knowledge-based criteria by which individuals could be admitted into, or kept out of, the profession.

We have tended to regard these organisational improvements as unproblematic and, indeed, necessary steps toward the improvement of health care altogether, both now and in the heyday of these standardising efforts. And it is true that these are the epistemological roots of our current health care system-standardisation as a practice and mode of medical inquiry was at least as important as the new experimental findings coming out of laboratories in this period $[12,38]$. The changes that standardisation wrought, however, came not through cooperation but most often through 
politics, with the triumph of points of view that often won out regardless of whether or not they reflected something we might call best practices [3, 29, 41].

In the well-known case of medical education's early 20th century standardisation in the United States, it was the pedagogies of a set of elite medical universities that won the standardisation battle [10]. It is certainly true that the medical curricular guidelines they drew up and enforced generally improved the state of medical education; however, it is less clear that these represented the best possible or most appropriate among those circulating at the time. Instructive in this vein are the earlycentury denunciations of individuals like the American standardising zealot Ernest Amory Codman, who glimpsed professional self-promotion (rather than best or even generalisable principles) as the primary driver of his colleagues' endeavours to set certain knowledge claims as standard [6, 13, 31]. Whether or not Codman's sense of his colleagues' motivations was accurate, he was certainly right in his recognition that the process by which standards were made was deeply subjective. A relatively small number of practitioners were in the unique position to decide what was 'best' and would become standard whether or not it suited the incredibly diverse medical landscape of the early 20th century United States [3, 41].

Following the history by which medical practice became standardised reveals the enormous significance medical standardisation had in its own right, as a process that rendered health legible. When everybody did the same thing, whether or not it was the best thing, it was much easier to police results, much easier to evaluate diagnostic and therapeutic practices, much easier to aggregate and communicate findings, much easier, indeed, to 'improve' the system. We have had a tendency to put the emphasis only on one part of medicine's knowledge production system- the purported quality of the data-when considering it historically. But it is retrospectively clear that it is the process of standardisation, and not just the material that was standardised, that deserves credit for medicine's resulting sea change. But while the standardisation of medicine itself was in many ways a great therapeutic and diagnostic boon, it also systemically undid any remaining sense that the particularities of the patient ought to be considered over and above diagnostic categories.

\section{The 'Care' of Health Care}

Part of the reason this new iteration of medicine 'worked' was because it matched growing sentiment about how knowledge of the public, its individual constituents and the world in which they lived should be described and reproduced in everyday life $[18,29]$. Modern medicine was coming to be in an age with a more general rising intellectual preference for a brand of knowledge that routinely displaced particular, material experiences in favour of universal conceptual structures, and the resulting system of health care created in great part by the success of standardising efforts proved impressively powerful. Its promotion of diagnostic categories over and above illness particularities not only shaped medical action in the early twentieth century, but also health care's trajectory and methodologies going forward, casting aside challengers that abstained from its populationcentric, statistical approach and creating a wide category of abnormality for ill 
bodies that did not conduct themselves in ways that were symptomatically consistent and categorically legible.

To be sure, some critics continued to echo Robertson throughout the early decades of the twentieth century, but the question of whether health care should 'care' was only really raised explicitly again in the aftermath of World War II when medical communities in both Britain and the United States were confronted with the possibility of a nationalized medical service. In both countries, the aversion of the medical community to health care's nationalisation was deep and intense. In the United States, the powerful American Medical Association (AMA) expressed one strand of the medical distaste for nationalised care: the loss of professional autonomy it potentially carried with it. To forestall this, the AMA undertook a successful propaganda campaign, a chief part of which rested on the circulation of the message that the intervention of the state would displace the caring, attentive doctor with one that was bureaucratic, cold, and impersonal. To this end, the AMA's public relations team put to especially good use a Victorian painting by Luke Fildes, entitled 'The Doctor' (1887), which depicted a besuited doctor in a young patient's modest home, keeping constant vigil, brow furrowed in concern, while the child's anguished parents looked on. Emblazoned with the tagline: 'Keep Politics out of this Picture,' the image helped to create an image of medicine not only as caring and personal but also as historically and vocationally so [42].

Though the AMA did not, of course, invent the notion that medicine should care, it did popularise and spread a very particular kind of claim about what that caring looked like. And this notion of caring was, from the start, oddly conflicted. Even as they held up a painting that idealised the physician's dedication to his patients and his investment in their health as their banner, the profession was promoting itself through a narrative of technological and institutional accomplishments [17]. Indeed, when read within the contemporary medical milieu, the Fildesian portrait of caring medicine seems more likely to invite the observation that this doctor might have had to care because he could not cure. But in fact, even in its own time, 'The Doctor' was not reflective of the state of medicine. Instead, Fildes was doing the same kind of propaganda work with his painting that the AMA would later use it to do: to show the doctor, as one physician put it in 1892, not necessarily as he is, but "as we would like [him] to be shown" [27]. The AMA was using for its marketing a painting that had been used for much the same purpose in the Victorian Era. This was nostalgia built on a nostalgia, with no true moment of caring as antecedent.

The wave of medical criticism toward the end of the 20th century did not let the conflicted nature of this 'caring' motif pass by unnoticed. Following the broader critiques of cultural structures at mid-century, a collection of critics began to view growing health care systems as fundamentally unconcerned with both caring and curing. The bureaucratic structures of government that the AMA harped on as threatening medicine were, in fact, the same structures that the medical establishment had adopted for itself. And the purpose of these structures, as some critics put it, was not to improve human health; instead, it was to amplify medicine's authority to adjudicate ever enlarging circles of human activity, such that increasing swathes of life were claimed for medicine [11]. This was, in many ways, the rightful-if a 
bit baleful—function of a modern system built in the first place on the imperative to standardise.

From about 1950-1970, the British physician and demographer Thomas McKeown launched a series of attacks on the medical system, arguing that improvements in health from the 18th century onward had been not the result of improved medical care, but rather the effects of more generally improved living conditions brought about by a more equitable distribution of wealth over time [24-26]. His contemporary Ivan Illich was even more scathing. Illich argued that disease and medicine ran at systemic tangents, with disease coming and going according to a logic that was utterly indifferent to medical intervention. Offering as one of his examples that, 'tuberculosis peaked over a 50-75 year period and declined before either the tubercle bacillus had been discovered or anti-tuberculosis programs had been initiated,' Illich concluded that 'no connection between changes in disease patterns can be attributed to the professional practice of medicine' $[19,20]$.

Other critics directed their attacks on the system in more immediate terms, picking apart moments in which medicine demanded a mode of thinking that was patently at odds with the care that the AMA had helped to popularise as an intrinsic part of medical practice. Perhaps the best-known and most eloquent voices here were those of the so-called 'anti-psychiatrists,' who noted the vast therapeutic gaps left between disease and experience of individuals diagnosed with a mental illness. The grand conceptual categories of disease, and the diagnostics and therapeutics they spawned, were unequivocally ill-equipped to deal with the immateriality and ephemeral workings of the human brain. The worry that Robertson had expressed in the early 19th century - that an iteration of medicine that relied on intellectual categories of disease would fail because illness was fundamentally a personal, material, individualised phenomenon — had for them been borne out [39].

Taken as a whole, these critiques articulated several of the larger and more worrying conceptual points that plagued medicine. For one thing, there were diseases that medicine could not, and would never, effectively capture. Its inability to 'see' what was meaningful in mental illness, for instance, suggested one disturbing proposition: that this iteration of medicine had been the wrong choice. Its articulation of disease entities in conceptual terms had given us a language and set of parameters for therapies, but the trade-off was that health could follow only one language, one logic, with diagnostics and therapeutics that adhered to one intellectual form. This recognition of the inadequacies of scientific medicine called out yet again the mismatch between the materiality of patient illness and the conceptual fixes that medicine could offer. And it brought up the thorny issue of how, if it was even possible, one might inject this system with the 'caring' required to meet contemporary needs.

It is out of these critiques that our current notions of care have arisen. The tendency of the arguments to rhetorically connect medical effectiveness or ineffectiveness in the main to a wide, uncaring and impersonal system created a new shorthand, such that 'care' became discursively essential to critiques of health care systems. Ironically, the AMA's attempts to appropriate caring as the exclusive domain of doctors in the $1940 \mathrm{~s}$ came back to haunt them decades later when critics began to measure the medical system the group had sought to defend from nationalisation by that very yardstick. 
In the decades since then, dissatisfaction with medical systems has consistently been expressed in terms of this rhetoric of caring. We have continued to bemoan, as we have for the last decades, medicine's failure to care. And yet, at the same time, as the vitriol of the mid-century critics quieted, we have also returned to a celebration of the results of our classifying, categorising, fundamentally uncaring, intellectually-oriented system of medicine. The result is an utter dissatisfaction with health care mixed with both a feeling of the inexorability of our current system and, more positively, an optimism associated with its successes nevertheless as an agent of health betterment.

\section{Austerity}

The discourse surrounding the impact of austerity on health repeats many of these themes, marking it not as a new and problematic interlocutor, but as the latest vehicle for the same longstanding doubts about our health system. It has particular use as a moral agent, blamed for violating the core interests of health and health care in its inhumane denial of services to needy patients on a global level, and the replacement of 'care' with efficiency protocols and cost-cutting measures at the local level $[1,32,34,36,40]$. Indeed, a 2017 special issue of Social Science \& Medicine goes so far as to describe policies of austerity concerning health care as reflective of the moral failing of the 'powerful:' those decision-makers who 'get to persistently frame our conversation' in ways most beneficial to them [1]. In this and other visions of the impact of austerity on health care, the role of austerity is often described as a mechanism of obstruction, if not destruction-one that prevents the practice of medicine as it would otherwise be: optimal, caring, beneficent.

Austerity's tacit invocation as a moral, rather than strictly economic, actor in the discussion surrounding health care has been well noted, even by economists. Florian Schui, for one, locates its point of origin in the concerns of the ancient Greeks about how to measure individual consumption in order to guard against the morally intolerable characteristics of decadence and hedonism that were associated with consuming too much. This consideration about the right way to live, he claims, ineluctably made its way into the political and cultural spheres, elevating the moral goods of 'moderation, sacrifice [and] selflessness,' from a concern of individuals keen to live well to a concern of culture and politics more generally [35].

Over the centuries, austerity has crossed over frequently from individual moral code to the cultural and political stage, even outside of explicit moments of austerity. The various trajectories of the early twentieth century efficiency movement in Europe and the United States, for example, strongly and explicitly designated the practices of austerity on a personal level as integral to the increased productivity and economic health of the nation. And even as plans for the great post World War II welfare spending projects, like the National Health Service, were coming to fruition in Britain, Prime Minister Clement Attlee was looking to austerity, in the figure of Sir Stafford Cripps-'austerity's arch prophet' - to fix the economy [7]. Variously described as both a 'selfless, gloomy scholar' and the consummate 'professional sourpuss,' Cripps got the job, it is said, not because of his aptitude for economic 
theory but for his personal commitment to asceticism. If Cripps could convince ordinary Britons to confine their metaphorical and literal diets to Spartan helpings of raw vegetables, as he himself did, Britain would make it out of the "economic wilderness' of postwar debt [7].

But austerity is more than the principles of asceticism writ large. It is also structurally configured as a kind of sociocultural 'penance' to the violation of the moral principles of appropriate consumption. In other words, it was the 'virtuous pain after the immoral party' of collective overconsumption, necessary to restore the moral status quo [35]. And it was indeed this penitential sense of austerity that was widely deployed after the 2008 financial collapse. As George Osborne, at the time chancellor of the Exchequer, put it in 2010: 'The truth is that the country has been living beyond its means. Today, we must pay off the debts of a failed past and lay the foundations for a more prosperous future' $[4,15,30]$. Whether or not austerity was the best policy for the country, his call for frugality and abstemiousness seemed to some an utterly natural, appropriate and even desirable solution that would restore the natural moral order.

In a general sense, it is probably already clear to many that it is the moral resonance of austerity, rather than any more nuanced accounting of its economic impact, that has become so critical in discussions about health care. One need look no further for evidence of this than the fact that though austerity has become one of our chief rhetorical tropes for expressing concerns about funding and health, the concerns themselves are by no means new. As one set of commentators pithily noted, health care systems remain imperfect, and vulnerable populations remain vulnerable, whether we are in a moment of austerity or not [1].

What is perhaps less obvious is that the discourse of austerity vis à vis health care is yet the latest expression of the same, ineffable, longstanding dissatisfaction with health care that has been our lot since the mid-twentieth century. Here, though, it is austerity that stands in for what health care perennially offers-utilitarian structures that systematically preclude caring-while the health care system that austerity endangers ironically comes to embody the 'caring' system that we wish health care would optimally be. Austerity's association with asceticism and penitence in particular shores up this image of caring medicine under attack, by those who would penalise the poorest for the overindulgences of the richest. However compelling this characterisation of austerity, it creates an image of health care that, by way of contrast, would dedicate itself at every level to caring - for individuals, groups, populations-if only it were left to its own devices. Much as we might like it to, the health care that austerity conjures up does not actually exist.

The dangers of describing health care systems as having been damaged or ruined by the imposition of political, economic, bureaucratic structures that constrain the caring part of health care are real. For one thing, they erroneously imply that austerity, once removed, will leave us with an ideal system of care. For another, they mislead us into believing that the problems of health care are really just one, singular, problem: of funding. And yet, even a quick glimpse of historical discussions of health care funding are enough to dispel this claim. From the earliest days of the National Health Service (NHS), for example, concerns about how much to spend on health care in order to ensure 'good health' turned on the knotty problem of deciding 
how to measure this 'good health' such that it could be appropriately monetized. As the NHS Royal Commission in 1979 pointed out, without an "objective or universally acceptable method of establishing what the 'right' level of expenditure on the NHS should be," there is no way to assess how much spending is enough [16].

Exploring this ambivalence about how much funding is enough, the historical commentator Rudolf Klein has suggested that in fact it is our uncertainty about how much good health costs that has made it a habit for some to always presume that the NHS is underfunded [21]. Whether we agree with Klein or not, his suggestion here is useful. In describing the problem of monetizing health as a problem of defining good health, Klein perhaps unwittingly describes where the conflicted last half century of health care has left us: without a clear vision of what it is that we want medicine to do and without a clear vision of how it ought to change, in order the better to accommodate the care we claim to seek. Indeed, it was this same, deep ambivalence that catalysed the intellectual challenges of Robertson, Illich, McKeown and others. And it is this same ambivalence which has caused us to define health care, over the last decade in terms of austerity, primarily through a discourse of intense dissatisfaction. We know health care, it would seem, chiefly in terms of what it is not.

To privilege austerity as we have damages our discussions by misleading us about the character and quality of health care more generally. Falling for a deceit perpetrated, if Schui and others are right, by austerity's masquerade as an economic policy, we have been misled about the cause and character of medicine's systemic problems. Rather than seeing the discourse surrounding austerity and medicine as one more rhetorical contrivance with which to reflect our conflicted sensibilities regarding medicine, we are encouraged to consider it instead as a moral failing of the state. In this way too, austerity has helped to extend the ruse that health care systems and the health they create are not culturally- and historically-contingent, but natural and moral entities.

The cultural theorist Mark Fisher made the pithy observation, in his 2009 Capitalist Realism, that one of the most telling indications of capitalism's grip on us is our inability to imagine any alternatives. Capitalism has become so innate, so indispensable to the fabric of our everyday lives, as to seem the only natural way to live: inexorable even when it is intolerable [9]. So it is with health care. Though we can clearly demonstrate that health care is a historically specific, constructed entity, with origins that definitely refute the view that our current system came into being because it was the best or most effective, we treat health care systems now as though they are inexorable-inexorable even when they are intolerable. Perhaps the most troubling element of the debates over austerity and health care is that they are blind, even obstructive, to alternatives. Instead, they reflect little more than the discursive inheritance of a longer history of expressing dissatisfaction with health care systems in the most oblique and least actionable of terms.

Open Access This article is distributed under the terms of the Creative Commons Attribution 4.0 International License (http://creativecommons.org/licenses/by/4.0/), which permits unrestricted use, distribution, and reproduction in any medium, provided you give appropriate credit to the original author(s) and the source, provide a link to the Creative Commons license, and indicate if changes were made. 


\section{References}

1. Basu, S., Carney, M. A., \& Kenworthy, N. J. (2017). Ten years after the financial crisis: The long reach of austerity and its global impacts on health. Social Science and Medicine, 187, 203-207.

2. Blyth, M. (2013). Austerity: The history of a dangerous idea. Oxford: Oxford University Press.

3. Bowker, G., \& Starr, S. L. (1999). Sorting things out: Classification and its consequences. Cambridge, MA: MIT Press.

4. Budget 2010: Full text of George Osborne's statement. 22 June 2010. The Telegraph. https://www. telegraph.co.uk/finance/budget/7846849/Budget-2010-Full-text-of-George-Osbornes-statement. html.

5. Collier, S., \& Lakoff, A. (2008). The problem of securing health”. In S. Collier \& A. Lakoff (Eds.), Biosecurity interventions. New York: Columbia University Press.

6. Crenner, C. (2001). Organizational reform and professional dissent in the careers of Richard Cabot and Ernest Amory Codman, 1900-1920. Journal of the History of Medicine and Allied Sciences, 56(3), 211-237.

7. Daniel, R. (1947). Austerity's prophet goes into action. New York Times, SM7.

8. Farr, W. (1842). Appendix to the fourth annual report of the Registrar-General of births, deaths and marriages. London: William Clowes and Sons.

9. Fisher, M. (2009). Capitalist realism: Is there no alternative?. London: Zero Books.

10. Flexner, A. T. (1910). Medical education in the United States and Canada. New York, NY: Carnegie Corporation.

11. Freidson, E. (1975). Profession of medicine: A study of the sociology of applied knowledge. New York: Dodd Mead \& Co.

12. Gainty, C. (2012). Going after the High-Brows: Frank Gilbreth and the Surgical Subject, 19121917. Representations, 118, 1-27.

13. Gainty, C. (2016). 'the autobiographical Shoulder of Ernest Amory Codman: Crafting medical meaning in the 20th century. Bulletin of the History of Medicine, 2016(90), 394-423.

14. Gere, C. (2017). Pain, pleasure and the greater good: From the panopticon to the Skinner Box and beyond. Chicago: University of Chicago Press.

15. Goodman, P. (2018). In Britain, austerity is changing everything. New York Times. May 23, 2018. https://www.nytimes.com/2018/05/28/world/europe/uk-austerity-poverty.html.

16. Gorsky, M. (2008). The British National Health Service 1948-2008: A review of the historiography. Social History of Medicine, 21(3), 437-460.

17. Howell, J. (1995). Technology in the hospital: Transforming patient care in the early twentieth century. Baltimore: Johns Hopkins University Press.

18. Igo, S. (2007). The Averaged American: Surveys, Citizenship, and the Making of a Mass Public. Cambridge: Harvard University Press.

19. Illich, I. (1974). Medical nemesis. Lancet, 303(7863), 918-921.

20. Illich, I. (1976). Medical Nemesis: The Expropriation of Health. New York, NY: Pantheon Books.

21. Klein, R. (2006). The new politics of the NHS. Oxford: Radcliffe Publishing.

22. McDaid, D., \& Knapp, M. (2010). Black-skies planning? Prioritising mental health services in times of austerity. British Journal of Psychiatry, 196(6), 423-424.

23. McDaid, D., et al. (2013). Health protection in times of economic crisis: Challenges and opportunities for Europe. Journal of Public Health Policy, 34(4), 489-501.

24. McKeown, T. (1976). The modern rise of population. New York, NY: Academic Press.

25. McKeown, T. (1976). The role of medicine: Dream, mirage, or nemesis?. London: Nuffield Provincial Hospitals Trust.

26. McKeown, T., Record, R. G., \& Turner, R. D. (1975). An interpretation of the decline of mortality in England and Wales during the twentieth century. Population Studies, 29, 391-422.

27. Moore, J. (2008). What Sir Luke Fildes' 1887 painting The Doctor can teach us about the practice of medicine today. The British Journal of General Practice: The Journal of the Royal College of General Practitioners, 58(548), 210-213.

28. Pfeiffer, J., \& Chapman, R. (2010). Anthropological perspectives on structural adjustment and public health. Annual Review of Anthropology, 39, 149-165.

29. Porter, T. (1996). Trust in numbers: The pursuit of objectivity in science and public life. Baltimore: Johns Hopkins University Press. 
30. Quilter-Pinner, H. (2018) Austerity is alive and well eight years on, no matter how many billions Theresa May gives to the NHS. 23 June 2018. https://www.independent.co.uk/voices/austerity-nhstheresa-may-billion-pounds-magic-money-tree-conservative-party-a8413151.html.

31. Reverby, S. (1981). Stealing the golden eggs: Ernest Amory Codman and the science and management of medicine. Bulletin of the History of Medicine, 55(2), 156-171.

32. Robertson, R., Wenzel, L., Thompson, J. \& Charles, A. (2017). Understanding NHS financial pressures: How are they affecting patient care? The King's' Fund. https://www.kingsfund.org.uk/sites/ default/files/field/field_publication_file/Understanding\%20NHS\%20financial\%20pressures\%20-\%20 full\%20report.pdf.

33. Rosenberg, C. (2002). The tyranny of diagnosis: Specific entities and individual experience. The Milbank Quarterly, 80(2), 237-260.

34. Ruckert, A., \& Labonté, R. (2017). Health inequalities in the age of austerity: The need for social protection policies. Social Science and Medicine, 187, 306-311.

35. Schui, F. (2014). Austerity: The great failure. New Haven, CT: Yale University Press.

36. Sparke, M. (2017). Austerity and the embodiment of neoliberalism as ill-health: Towards a theory of biological sub-citizenship. Social Science and Medicine, 187, 287-295.

37. Stuckler, D., \& Basu, S. (2013). The body economic: Why austerity kills. New York, NY.: Basic Books.

38. Sturdy, S., \& Cooter, R. (1998). Science, scientific management, and the transformation of medicine in Britain, c. 1870-1950. History of Science, 36, 420-466.

39. Szasz, T. (1976). The Myth of mental illness: Foundations of a theory of personal conduct. New York: Harper and Rowe.

40. The King's Fund. The impact of NHS financial pressures on patient care. Retrieved June 1, 2019 from https://www.kingsfund.org.uk/projects/impact-nhs-financial-pressures-patient-care.

41. Timmermans, S., \& Berg, M. (2003). The gold standard: The challenge of evidence-based medicine. Philadelphia: Temple University Press.

42. Warner, J. H. (2014). The Fielding H. Garrison Lecture: The Aesthetic grounding of modern medicine. Bulletin of the History of Medicine, 88(1), 1-47.

43. Weaver, J., \& Munro, D. (2013). Austerity, neo-liberal economics, and youth suicide: the case of New Zealand, 1980-2000. Journal of Social History, 46(3), 757-783.

Publisher's Note Springer Nature remains neutral with regard to jurisdictional claims in published maps and institutional affiliations. 